\title{
Households' preferences and willingness to pay for multiple use water services in rural areas of South Africa: An analysis based on choice modelling\#
}

\author{
P Kanyoka ${ }^{1}$, S Farolfi ${ }^{2 *}$ and S Morardet ${ }^{3}$ \\ ${ }^{1}$ Department of Agricultural Economics, University of Pretoria and IWMI MSc Fellow \\ ${ }^{2}$ CIRAD UMR G-EAU and CEEPA, University of Pretoria \\ ${ }^{3}$ Cemagref UMR G-EAU and IWMI, Southern Africa Office
}

\begin{abstract}
Financing of multiple use (i.e. domestic and productive) water services was identified as an important ingredient to ensure improved water access for rural poor and broaden livelihood options in South Africa. Following the principles of integrated water resource management (IWRM), efficient, equitable and sustainable investments in improved water services should be based on a thorough understanding of actual demand by consumers. Comprehensive studies looking at multiple use water services are not common in South African rural areas, where most of the economic analyses focus on either domestic or irrigation water demand. This study aims at filling this gap by assessing the household demand for multiple use water services in Sekororo-Letsoalo area in the Limpopo Province. Choice modelling is the approach used to identify the attributes determining demand for water services and quantify their relative importance. Results show that households in rural areas are willing to pay for improvements in water services. Due to the current poor level of water services in the area, users are primarily concerned with basic domestic uses and, consequently, demand for productive uses is low. Only households already relatively well served are interested in engaging in multiple water uses.
\end{abstract}

Keywords: choice modelling, multiple water uses, domestic water demand, water services, willingness to pay

\section{Introduction}

Water scarcity is considered to be a major constraint to socioeconomic development in South Africa (SA) (DWAF, 2004). In most parts of the country water resources are already fully utilised or overdrawn. The agricultural sector is the highest consumer of water, accounting for about $62 \%$ of the total water used, while domestic and industry water uses represent $32 \%$ (5\% in rural areas) and 6\% respectively (AQUASTAT, 2005).

Following the principles of integrated water resource management (IWRM), the efficient and equitable allocation of water resources involves important trade-offs between different potential users. At the projected population growth and economic development rates, it is unlikely that the national demand for water resources will be met in the near future. Conversely, increased competition among water users for the scarce resource can be expected. High pollution levels of surface and groundwater resources due to industrial effluents, domestic and commercial sewage and agricultural runoff, contribute to worsen this situation (DWAF, 2003).

Domestic water uses in SA are characterised by significant inequities in terms of access to the resource and quality of services inherited from the apartheid era policies of 'separate development'. To redress this situation, several institutional and

\footnotetext{
Revised version. Originally presented at the International Conference on Integrated Water Resource Management (IWRM) entitled: Lessons from Implementation in Developing Countries which took place from 10 to 12 March 2008 in Cape Town, South Africa, at the Cape Town International Convention Centre.

* To whom all correspondence should be addressed.

+27 12 4204659; fax: +27 12 4204958;

e-mail: stefano.farolfi@up.ac.za
}

policy reforms were undertaken after the end of apartheid. The Water Services Act of 1997 and the National Water Act of 1998 provided the legislative framework for water services and water resource management respectively (Republic of South Africa, 1997a; b; and 1998). Under the Water Services Act, provision of free basic water $(25 \ell / c a p \cdot d)$ and sanitation services for all end users was considered a priority (DWAF, 2004).

In addition to the provision of free basic water, financing of multiple use water services was identified as an important ingredient to ensure improved access to water for rural households and at the same time allow productive uses and broaden livelihood options for the poor in SA (Lefebvre et al., 2005; Hope et al., 2003; Van Koppen et al., 2006). Recent evidence has indicated the potential contribution that productive use of domestic water might make to food security and poverty reduction in rural areas of SA (Hope et al., 2003; Hope and Garrod, 2004; Smits et al., 2006).

However, free provision of water above the basic level is not without risk, as, if not carefully controlled and managed, it could place unsustainable demand on a resource already under pressure. Furthermore, the necessary public investments to provide additional water would represent a financial burden for the local and central governments. An option to make financially viable the increased and improved water services in rural areas could come from the (partial) coverage of the investment and operating costs determined by these services through the introduction of water user fees. To this purpose, some authors indicate that the raising of revenue from consumers is central to cost recovery of current investments and future up-scaling of water services (Goldblatt, 1999).

Efficient, equitable and sustainable investment in improved water services should be based on a thorough understanding of effective consumers' demand for multiple use (both domestic 
and productive) water services (Whittington et al., 1998). Such studies are not common in SA rural areas, where most of the research projects to date focus on either domestic water uses (Banda et al., 2006 and 2007) or irrigation water uses (Nieuwoudt et al., 2004; Speelman et al., 2008). The present study aims at filling this gap by assessing the household demand for multiple use water services in the Sekororo-Letsoalo area (Maruleng municipality, Limpopo province) located in the Olifants River basin.

After having described the characteristics of water users and uses in the study area, the paper applies the choice modelling (CM) approach to estimate the relative importance of selected characteristics (attributes) of water services and possible uses for different typologies of local households. The CM approach is then used to elicit local households' willingness to pay (WTP) for an improvement in the level of water services.

\section{Analytical framework}

Two main economic approaches, both of them under the category of the stated preferences methods, are usually employed to assess individual or household's demand for water: the contingent valuation method (CVM) and the CM approach. CVM is a common survey-based procedure for eliciting the economic value of the quality and availability of non-market commodities (Nicklitschek and Leon, 1996). In implementing a CVM survey, respondents are presented with questions on whether or not they are willing to pay/be reimbursed for a change of some characteristics of the commodity in question. Respondents are therefore facing a dichotomous choice.

$\mathrm{CM}$ (or choice experiments, as the approach will alternatively be named later on in this paper) is a generalisation of the CVM in that it gives respondents a menu of alternative scenarios characterised by several attributes, from which they have to choose (Adamowicz et al., 1998). Respondents compare the available options and choose the one that maximises their utility. As compared to CVM where the focus is on willingness to pay, $\mathrm{CM}$ allows the researcher to pose to the respondents a number of constructs to understand the influence of variations in the level of attributes on their choice (Adamowicz, 1995; Louviere, 1996). According to Anand (2001), CM makes it '... easier to estimate the value of the individual attributes that make up an environmental good...This is important since many management decisions are concerned with changing attribute levels'. CM is also useful for analysis of situational changes and trade-offs between attributes (Snowball et al., 2007; Hope and Garrod, 2004).

Data for CM are generated by systematic and planned procedures where attributes and levels are predefined to create choice alternatives.

The theoretical foundations of $\mathrm{CM}$ are in the random utility theory (RUT) (Ben-Akiva and Lerman, 1985; McFadden, 1973). The hypothesis of the RUT is that individuals make their choices based on the characteristics of the good along with a random component. The random component may be a result of the uniqueness of preferences of the individual or because the researchers may not have complete information about the individual. The theory therefore states that the utility $U_{i j}$ of an individual $i$ derived from a scenario $j$ is not known but can be decomposed into a deterministic component $V_{i j}$ and an unobserved random component, $\varepsilon_{i j}$ :

$$
U_{i j}=V_{i j}+\varepsilon_{i j}
$$

where:

$V_{i j}$ can be expressed as a linear function of the explanatory variables as follows:

$$
V_{i j}=x_{i j}^{\prime} \beta
$$

where:

$\beta$ is a vector of coefficients associated with the vector $x$ ' of explanatory variables, which are attributes of scenario $j$, and these include price, and the socioeconomic factors of individual $i$ (Snowball et al., 2007; Greene, 2000).

The individual $i$ would be assumed to choose alternative $j$ over alternative $k$ if $U_{i j}>U_{i k}$.

The assumptions placed on the random component of the utility define the statistical model utilised. Given that the explanatory variables are attributes, a conditional logit model (CLM) was used in this study. For the CLM it is assumed that the error disturbances have a type 1 extreme value distribution:

$$
\exp \left(-\exp \left(-\varepsilon_{i j}\right)\right)
$$

The selection of an alternative can be expressed as:

$$
\mathrm{U}_{\mathrm{ij}}>\max _{k} \in_{c i, k \neq j} U_{i k}
$$

Applying the CLM, the probability of choosing an alternative $j$ among $n$ choices for individual $i$ is:

$$
\begin{aligned}
& P_{i}(j)=P\left[x_{i j}^{\prime} \beta+\varepsilon_{i j} \geq \max _{k} \in_{c i}\left(x_{i k}^{\prime} \beta+\varepsilon_{i k}\right)\right] \\
& =\exp \left(x_{i j}^{\prime} \beta\right) / \sum_{k} \in_{c i} \exp \left(x_{i k}^{\prime} \beta\right)
\end{aligned}
$$

This means that the probability that the individual $i$ chooses $j$ is equal to the probability that the utility derived from $j$ is greater than the utility derived from any other alternative (Whittington et al., 1990).

The most common econometric models used to process data in CM are the multinomial logit model (MLM), the nested multinomial logit (NML), and the conditional logit model (CLM). The MLM is applied to data where household characteristics are included in the model as explanatory variables. The NLM is a generalisation of the MLM, which is applied when the choices are sequential and logically grouped into a two-level decision tree (the $1^{\text {st }}$ decision consists in choosing between the status quo and a change; the $2^{\text {nd }}$ decision corresponds to a choice between two changing options). CLM is applied to data where the explanatory variables only include attribute levels of the good. This study aimed to establish which types of water services households prefer to understand, particularly whether or not they prioritise water services that cater for multiple uses, therefore the attribute levels (water quantity, quality, source, price, productive uses and frequency of availability) were used as explanatory variables. In addition, there was no status quo in the experiment (i.e. choices were not sequential). For these reasons, a CLM was applied (Greene, 2007).

$\mathrm{CM}$ has been used recently by several authors in various parts of the world to value water services. Blamey et al. (1999) applied choice modelling to assess the value of water in communities with different water supply options in the Australian Capital Territory. Hope and Garrod (2004) and Hope (2006) applied choice experiments in a rural area in Limpopo Province, South Africa, to examine the preferences of households for changes in domestic water services. Yang et al. (2006) examined factors that influence the demand for alternative water supply and 
sanitation services in Negombo, Sri Lanka. Snowball et al. (2007) applied choice modelling to elicit the household's willingness to pay for improvement in water attributes in the middle income urban area of South Africa. And finally, Nam and Son (2005) carried out a study to assess the willingness to pay for improved water services and the consumers' preferences for water services of households in Ho Chi Minh City, Vietnam. However, with the partial exceptions of Hope and Garrod (2004) and Hope (2006), multiple uses of domestic water are not contemplated. This study aims at filling this gap, by introducing 'productive uses' as a specific attribute in the CM.

\section{Research methods}

\section{Study area}

This study was carried out in the Sekororo-Letsoalo area, located within the quaternary catchment B72A of the Olifants River basin, in the Limpopo Province of SA. This research site is part of the Sekororo and Letsoalo tribal authorities and is located in Maruleng Local Municipality, Mopani District, which during apartheid was part of the Lebowa homeland.

The study area includes 14 villages where 56510 inhabitants live, according to the Bohlabela District Water Services Development Plan (Tumber Fourie Consulting Engineers, 2003a).. According to Statistics SA (2001), $89 \%$ of the population in this area earns less than R1 620/month, and $95 \%$ is considered very poor (meaning that they have a monthly income of R800 or less), the majority depending on the government social grants for a living. Studies carried out in 2005 in 10 villages in the area by the NGO World Vision showed that $39 \%$ of the sampled population relies on pensions and child grants, whilst only $31 \%$ can count on regular salaries and less than $3 \%$ of the households derive an income from cultivation of small plots. At least $4 \%$ of the local households are reported to have no source of income at all (World Vision, 2005a and b).

Services and infrastructures for the provision of domestic water are rudimentary in the study area. Domestic water networks in the villages are generally composed of one or more boreholes or a weir diverting water from a stream, one to three reservoirs and a small reticulation system supplying public standpipes. Most of these networks were built in the 1980s during apartheid by the government of the Lebowa homeland, with limited improvements (weirs, reservoirs) and extensions after 1994. After a period of transition, during which the Department of Water Affairs and Forestry (DWAF) was in charge of managing the water services, networks have been handed over to the Mopani District Municipality. In recent years, some households paid for a private water connection in the yard or within the house premises. However, due to the poor global efficiency of the water schemes deriving from low quality of the initial network's design and the insufficient maintenance of the infrastructure, interviewees reported that water supply is unreliable and quantity supplied inadequate.

Water access and water services vary across villages. The percentage of households having access to private taps (inside yard and in-dwelling) ranges from $20 \%$ to $65 \%$, with an average of $40 \%$ for the whole area (Statistics SA, 2001). Other sources of domestic water include public standpipes, vendors, boreholes and rivers/streams. Households do use water for productive purposes in the area such as gardening, communal farming ( $42 \%$ of households), and livestock breeding (63\% of households) (World Vision, 2005a and b).

\section{Data collection}

This study is based on both primary and secondary data. The secondary data were drawn from government and research publications as well as from students' dissertations (Statistics SA, 2001; Tumber Fourie Consulting Engineers, 2003b; World Vision, 2005a; b; Panesar, 2006. Primary data came from focus groups conducted with local stakeholders and household surveys. Focus group discussions were run in two of the 14 villages in the area in order to identify and validate the attributes to be used in the choice experiment and to calibrate significant levels for these attributes. The 2 villages were selected as they have, respectively, relatively good access to water and very poor access to water in the area (in terms of rainfall, presence of perennial rivers and irrigation schemes).

A structured questionnaire was used to collect quantitative data about the households and implement the choice experiment. The content of the questionnaire on household characteristics was guided by previous research on determinants of rural households' demand for water services. Six enumerators (M.Sc. students from the University of Limpopo) speaking the local language (Pedi) were trained to interview the selected households.

\section{Experimental design and sampling procedure}

The focus group study allowed identifying water service attributes and levels used to design the options to be submitted to interviewed households in the form of choice cards (cf. Table 1, next page). The last column of Table 1 shows the expected signs of the coefficients linked to each attribute. These signs represent the preferences of the respondents according to the microeconomic theory. For instance, it is expected that a household would prefer lower water prices (negative sign of the coefficient for water price) combined with higher water availability (positive sign of the coefficient for water quantity).

In order to reduce the number of attribute and level combinations for the experiment, an orthogonal design was used to allow an investigation of 'main' effects without being able to detect all interactions between attributes (Hanley et al., 2001). This is quite sufficient, since main effects usually count for 80 to $90 \%$ of the variation in the data of choice experiments (Willis et al., 2005; Snowball et al., 2007). The statistical package SAS was used to conduct the orthogonal design.

The population to be surveyed was divided into two strata. Stratum 1 includes those households without private taps (in the dwelling or in the yard), while Stratum 2 is composed by households with private taps. All attributes (6) indicated in Table 1 were presented as choice determinants to Stratum 1, whilst the attribute 'source of water' was not part of the choice sets for Stratum 2. The orthogonal design allowed generating 24 water service alternatives (sets of attributes' levels) for Stratum 1 and 18 sets for Stratum 2. This set-up had D efficiency, A efficiency and $\mathrm{G}$ efficiency indicators of higher than $96 \%$. These indicators measure the goodness of the design relative to the hypothetical design that may be far from possible (Kuhfeld, 2000). The 24 and 18 combinations for the two strata were then paired into 12 and 9 choice cards respectively, each containing two alternative sets, from which the respondents were asked to select one. At least 3 cards (one at a time) were presented to each surveyed household.

A sample of 150 households was initially considered representative (2.3\% of the population). The study was then conducted in 7 villages in the Sekororo-Letsoalo area where 169 households (62\% belonging to Stratum 1 and $38 \%$ to Stratum 2$)$ were 


\begin{tabular}{|c|c|c|c|}
\hline \multicolumn{4}{|c|}{$\begin{array}{c}\text { TABLE } 1 \\
\text { Attributes and levels used in the Sekororo-Letsoalo choice modelling study }\end{array}$} \\
\hline Attributes & Description & Levels & $\begin{array}{l}\text { Expected ef- } \\
\text { fect on choice }\end{array}$ \\
\hline Quantity of & $\begin{array}{l}\text { Quantities of water used for domestic purposes across } \\
\text { households in the study area range from } 75 \text { litres to } 200 \\
\text { litres per household per day. According to the focus group } \\
\text { discussions held, households would like to use more water } \\
\text { than what they currently do if only this water was avail- } \\
\text { able. }\end{array}$ & $\begin{array}{l}\text { - } \quad 3 \times 25 \ell \text { containers per day } \\
\text { - } \quad 6 \times 25 \ell \text { containers per day } \\
\text { - } \quad 12 \times 25 \ell \text { containers per day } \\
\text { - } \quad>12 \times 25 \ell \text { containers per day }\end{array}$ & Positive \\
\hline $\begin{array}{l}\text { Frequency of } \\
\text { water supply }\end{array}$ & $\begin{array}{l}\text { Currently piped water is not available at all times. In most } \\
\text { of the surveyed villages households get piped water only } \\
\text { two times a week. Water sources such as rivers are not } \\
\text { reliable because of seasonality of the hydrological cycle. }\end{array}$ & $\begin{array}{l}\text { - } \\
\text { - Warrent } \\
\text { hours everyday } \\
\text { Water available all times of the } \\
\text { day everyday }\end{array}$ & Positive \\
\hline $\begin{array}{l}\text { Qualit } \\
\text { water }\end{array}$ & $\begin{array}{l}\text { Most of the households in the area complain that the water } \\
\text { they drink is not of good quality even though there is no } \\
\text { clear evidence of water borne diseases. In some villages } \\
\text { inhabitants complained that piped water is salty or muddy } \\
\text { and hence they cannot drink it or use it for cooking. } \\
\text { Quality of water could not be assessed through direct } \\
\text { analysis. }\end{array}$ & $\begin{array}{ll}- & \text { Current } \\
- & \text { Purified }\end{array}$ & Positive \\
\hline Price of water & $\begin{array}{l}\text { Currently households in Sekororo-Letsoalo area do not } \\
\text { pay a monthly bill for water. } \\
\text { A tariff could be introduced to cover part of the costs of } \\
\text { water provision and services. }\end{array}$ & $\begin{array}{ll}\text { - } & \text { R0 per month } \\
\text { - } & \text { R10 per month } \\
\text { - } & \text { R50 per month } \\
\text { - } & \text { R100 per month }\end{array}$ & Negative \\
\hline $\begin{array}{l}\text { Productive } \\
\text { uses }\end{array}$ & $\begin{array}{l}\text { Some households in Sekororo-Letsoalo area use water } \\
\text { for productive uses like backyard garden irrigation, beer } \\
\text { making, and house building. At present they complain } \\
\text { that water quantity and reliability are insufficient to allow } \\
\text { productive uses. In addition, some water providers do not } \\
\text { allow people to use piped water for productive uses. }\end{array}$ & $\begin{array}{ll}- & \text { Current } \\
\text { - } & \text { More }\end{array}$ & Positive \\
\hline $\begin{array}{l}\text { Source of } \\
\text { water }\end{array}$ & $\begin{array}{l}\text { The main sources of water used in the area are private taps, } \\
\text { public standpipes, rivers, boreholes, springs, and rainwa- } \\
\text { ter. The source of water has a vital impact on the quantity, } \\
\text { frequency of supply and quality of water consumed by a } \\
\text { household. }\end{array}$ & $\begin{array}{ll}\text { - } & \text { Current water source } \\
\text { - } & \text { Private tap }\end{array}$ & Positive \\
\hline
\end{tabular}

interviewed. Selection of the villages was based on the type of water access according to the 2001 Census and the distance from the mountains (proxy for water availability). The submission of an average of 4.8 cards to each respondent resulted in a number of available observations of $169 \times 4.8 \approx 811$.

\section{Results and discussion}

\section{Socio-economic characteristics of the respondents}

The majority of respondents were household heads (64\%), aged between 19 and $86.77 \%$ were women, which could be considered an advantage from the information point of view as women are generally more aware about household water uses and sources. Respondents' educational level is very low, as almost $60 \%$ did not reach secondary school and 30\% did not receive any formal education. Unemployment rate is high: $64 \%$ of household heads are not employed. The average household income is R1 654/month and the overall distribution of income is highly skewed. About $76 \%$ of the households can count on a monthly income of lower than R1 $600.51 \%$ of the households rely on pensions whilst only $29 \%$ receive monthly salaries.
Household size ranged from 5 to 8 members, with an average of 6 for the whole sample.

\section{Characterisation of water uses and users}

Per capita water consumption was found below the Reconstruction and Development Programme (RDP) standard (25 l/cap.d) for $41 \%$ of the households. Water supply frequency and reliability is a major problem: only $18 \%$ of respondents declared that they have access to a source of water every day at any given time, whilst almost $80 \%$ do not have daily access to water. Households often resort to several water sources to meet their needs and have invested in storage capacity to cope with unreliability of water supply. As a result of this situation, $71 \%$ of respondents were willing to pay a once-off connection fee for an improved water service. Households not willing to pay were characterised by lower water consumption, educational level and per capita income. Gender of the respondents had an impact on the willingness to pay for water network refurbishment, as men were found not willing to pay more often than women. Respondents gave priority to water for domestic purposes before they could engage in productive uses. A small proportion of households 
(those consuming relatively higher quantities of water or having a more frequent access to water) currently uses domestic water for multiple purposes.

\section{Determinants of rural households' water demand and willingness to pay for water services}

A Conditional Logit Model (CLM) was adopted to interpret the data collected through the choice experiment. The dependent variable for this model was the choice of a water alternative whilst the explanatory variables were represented by the attributes of water service. Alternatives to be selected by respondents consisted in different combinations of attributes' levels.

As indicated in the previous section, the sample was initially split into two strata: households without access to a private tap (Stratum 1) and households with access to a private tap (Stratum 2). During data processing, the sample was further stratified on the basis of household's water consumption and household's income. This sub-stratification led to the typology of households described later in the text.

Tables 2 to 7 and Figs. 1 to 3 present the results of the CLM for the different strata and sub-strata of the sample. For each attribute (variable), figures and tables illustrate the following indicators: estimated coefficients of the CLM regression, antilog of the coefficients, implicit prices (ratio of attribute coefficient/ price coefficient), and significance of the coefficients.

Calculating the antilog of the CLM coefficient allowed interpreting the probability of a respondent's choice for a water services alternative that includes a change of level in the corresponding attribute. Implicit prices show the respondents' willingness to pay for improvement of the attributes. The overall performance of the regression can be assessed by looking at the McFadden $\mathrm{R}^{2}$ value, which corresponds to the proportion of the variance of the dependent variable explained by the variance in the independent variables. This value is a scalar measure of between 0 and 1. A model would be acceptable if its McFadden $\mathrm{R}^{2}$ value ranges between 0.2 and 0.4 (Koutsoyannis, 1992).

\section{Preferences for water services of households with and without private taps}

Results for Stratum 1 (households without private taps) are presented in Table 2. All coefficients except for 'productive uses' are significant and, with the exception of 'price', positive, implying that increases in each of these attributes are desirable to the respondents. The respective values of the attribute coefficients (or the antilog coefficients) show that households without a private tap put more emphasis on water source, quality and frequency of supply (in this order) than on other attributes in their choice of water services.

Implicit prices, calculated only for significant coefficients, show that households without private taps would be willing to pay for an improvement in the water service. Willingness to pay (WTP) of R0.1/month for an increase of $1 \mathrm{l} / \mathrm{d}$ was estimated (equivalent to $\mathrm{R} 3.3 / \mathrm{m}^{3}$ ). This value is in line with the price of water charged in similar contexts (for example Lefevbre et al. (2005) reported that in Polokwane Municipality, water is charged at $\mathrm{R} 2.1 / \mathrm{m}^{3}$ for the first $5 \mathrm{~m}^{3}$ and $\mathrm{R} 3.2 / \mathrm{m}^{3}$ between 5 and $10 \mathrm{~m}^{3}$ of monthly consumption). To understand the potential of recovery of some of the water supply costs, this value can also be compared to the estimated full cost (including capital cost) of the projected water supply project in the area $\left(\mathrm{R} 10 / \mathrm{m}^{3}\right)$. Similarly, a WTP of R14.6/month was observed for an improvement in the frequency of supply from one level to the next. Quality of water is also an important determinant for households' WTP, as households would pay R19.4/month for purification of water. However, the highest WTP of households was shown for access to a private tap and this corresponded to R27.7/month (ZAR at the time of writing is worth approximately R10 per 1 US\$).

\begin{tabular}{|c|c|c|c|}
\hline \multicolumn{4}{|c|}{$\begin{array}{c}\text { TABLE 2 } \\
\text { CLM results for Stratum 1: Households without } \\
\text { private taps }\end{array}$} \\
\hline Variable & $\begin{array}{l}\text { Antilog of } \\
\text { coefficient }\end{array}$ & $\begin{array}{c}\text { Implicit } \\
\text { Price }\end{array}$ & $P[|Z|>z] \mid$ \\
\hline Quantity & 1.01 & 0.10 & 0.005 \\
\hline Frequency of supply & 3.66 & 14.63 & 0.000 \\
\hline Quality & 5.61 & 19.44 & 0.023 \\
\hline Price & 1.09 & 1.00 & 0.000 \\
\hline Productive uses & - & - & 0.756 \\
\hline Water source & 11.61 & 27.67 & 0.000 \\
\hline
\end{tabular}

Results from Stratum 2 (households with private taps) are shown in Table 3. The same attributes used for Stratum 1, with the exception of 'source of water', were included in the choice experiment for this stratum. All the coefficients were significant with the exception of 'productive uses'.

\begin{tabular}{|l|c|c|c|}
\hline \multicolumn{4}{|c|}{ TABLE 3 } \\
CLM results for Stratum 2: Households with private \\
taps \\
\hline Variable & $\begin{array}{c}\text { Antilog of } \\
\text { coefficient }\end{array}$ & $\begin{array}{c}\text { Implicit } \\
\text { Price }\end{array}$ & P $[|\mathbf{Z}|>\mathbf{z}] \mid$ \\
\hline Quantity & 1.00 & 0.06 & 0.004 \\
\hline Frequency of supply & 1.56 & 6.60 & 0.071 \\
\hline Quality & 2.19 & 11.74 & 0.046 \\
\hline Price & 1.07 & 1.00 & 0.000 \\
\hline Productive uses & - & - & 0.164 \\
\hline
\end{tabular}

Number of households $=87 ;$ McFadden $R^{2}=0.21$

The price elasticity of demand for water (price coefficient) was higher for households without private taps compared to households with private taps. This can be due to the fact that the former households are poorer than the latter, and therefore more sensitive to price. The average monthly per capita income for households without private taps was calculated at R248, compared to R462 for households with private taps. For the two strata, estimations are significant and consistent with the findings of Snowball et al. (2007), who showed that water price was very significant for households living in an urban area of South Africa (Grahamstown). Households with private taps have a higher preference for productive uses. This could be due to the fact that, unlike households without private taps who are still worried about meeting their basic water needs, their water supply is sufficient in terms of quantity and reliability to allow them engaging in non domestic water uses.

An improvement in the quantity of water available has almost the same impact on preferences of the two groups of households (Fig. 1). Conversely, an improvement of the frequency of water supply is perceived as more important for households without private taps. This could be interpreted as a perception of water availability by these households more related to the access to the water source and to its reliability rather than to the physical quantity of water available. The very high coefficient of "water source' for the households without private tap confirms the influ- 

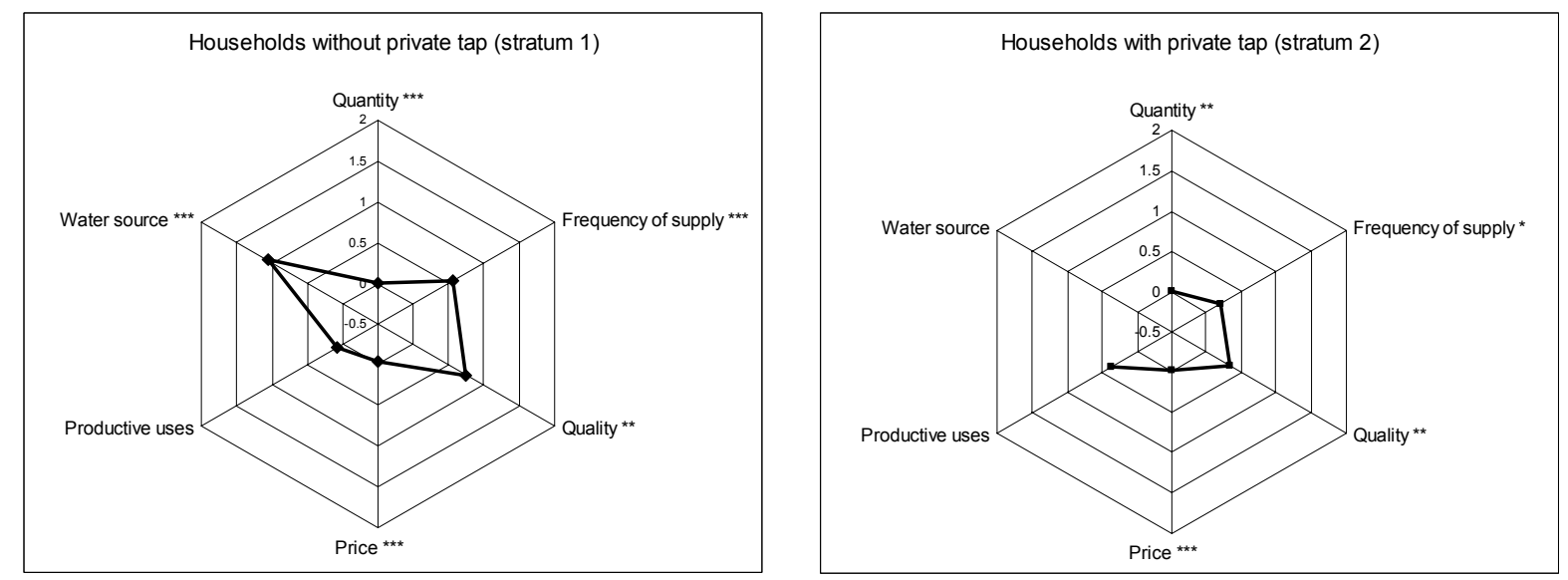

$*$ significant at $10 \% ; * *$ significant at $5 \% ; * * *$ significant at $1 \%$

Figure 1

CLM coefficients of attributes for Strata 1 and 2
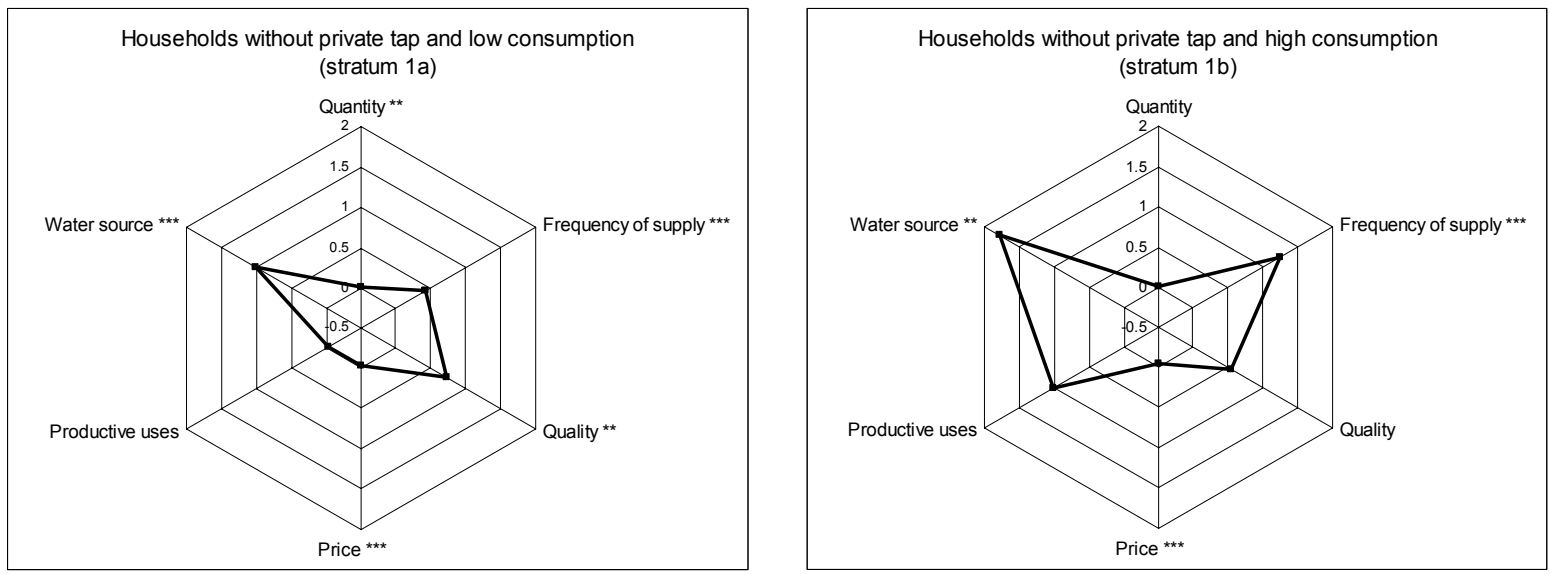

Figure 2

CLM coefficients of attributes for Strata $1 \mathrm{a}$ and $1 \mathrm{~b}$

ence of the physical presence of a reliable tap close to homestead in terms of preferences for the water services.

Both groups of households allocate higher relevance to a water quality improvement rather than to a better frequency of supply. This is due to the strong concern about the generally poor qualitative level of the resource. However, because of the poor quality conditions of water collected from the rivers/ streams and sometimes even from collective taps in the area, households without private taps allocate even higher importance to this attribute than households with private taps.

\section{Household's water consumption and preferences for water services}

In order to interpret more precisely the results from the two strata illustrated above, it appeared worthwhile to further stratify the household sample according to the current household's consumption of water per day. The average consumption of water for the entire surveyed sample was estimated at $150 \mathrm{\ell} / \mathrm{d}$. It was then decided to consider 'households with lower water consumption' those consuming less than $150 \mathrm{l} / \mathrm{d}$ and 'households with higher water consumption', the remaining ones.

The introduction of this new variable allowed splitting the total sample into four sub-strata: 'households without private tap and lower water consumption' (sub-stratum 1a); 'household without private tap and higher water consumption' (sub-stratum 1b); 'households with private tap and lower water consumption' (sub-stratum 2a); 'households with private tap and higher water consumption' (sub-stratum 2b). Tables 4 and 5 and Figs. 2 and 3 present the results of a CLM applied to the four sub-groups of households.

Results show that in the group without private taps (Fig. 2), the requirement of a closer and more reliable source of water supply is stronger in households where current water consumption is higher. For households consuming more water, the coefficient of the attribute 'productive uses' (even if not significant) is positive and higher than the one observed in strata 1 and 1a, confirming that higher current water consumption, which is linked to current availability, induces more interest in non domestic water uses. Households without private taps consuming more water are less concerned with water quality but more concerned with water price, as (relatively) high consumption of a more expensive resource would have a negative influence on their family budget.

Interestingly, when private taps are available (Fig. 3 and Tables 4 and 5), the frequency of supply is less important for households already consuming more water. This result is consistent with findings from other researchers. Farolfi et al., 2006; Hope, 2006; Hope and Garrod, 2004; Yang et al., 2006 and Pattanayak et al., 2006, found that a negative relationship exists between WTP for quantitative water improvements (including frequency of supply) and current household water consumption. 

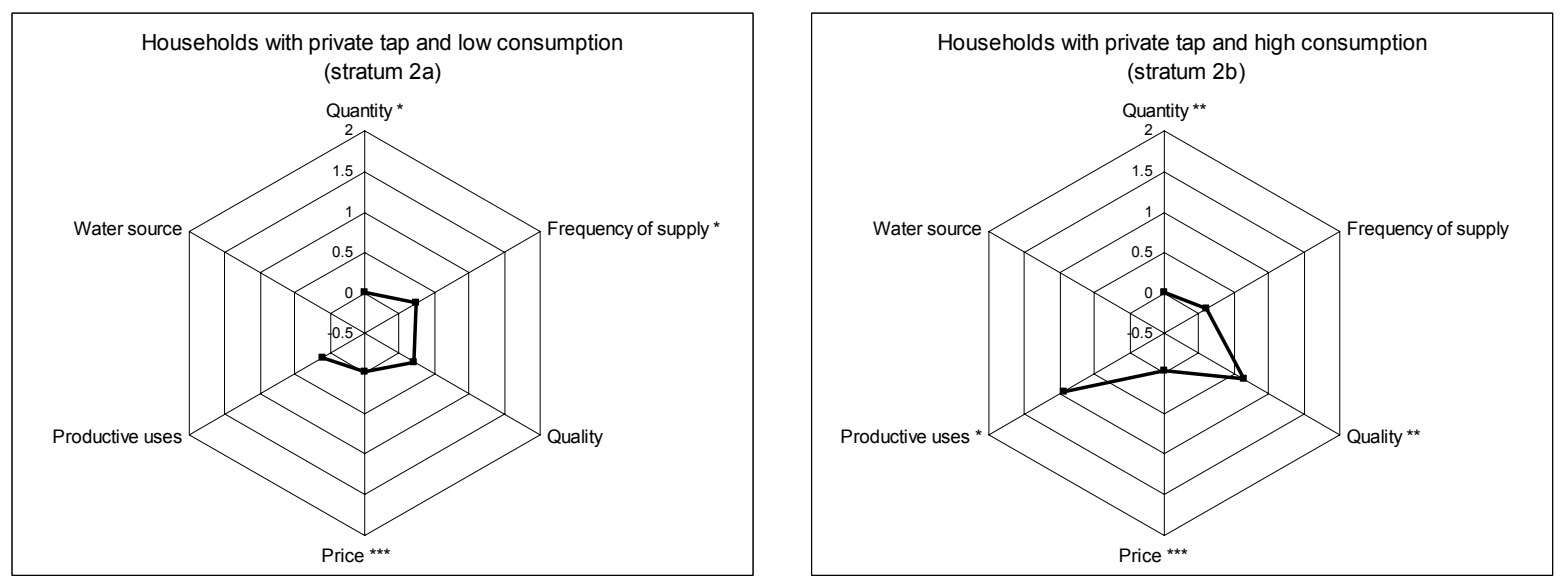

Figure 3

CLM coefficients of attributes for Strata $2 a$ and $2 b$

The higher coefficient for the attribute 'productive uses' when consumption is higher seems to confirm the hypothesis about the emergence of the interest for multiple uses once basic needs are satisfied, although further analyses to reach a clearer understanding of this phenomenon are required. It is worthwhile noticing, finally, that the McFadden $\mathrm{R}^{2}$ for the CLM shown in Table 4 is 0.17 , therefore slightly out of the 0.2 to 0.4 range required for a sufficient goodness of the estimation. This is probably due to the limited number of households belonging to this group.

\section{TABLE 4}

Sub-Stratum 2a. Households with private tap and lower water consumption

\begin{tabular}{|l|c|c|c|}
\hline Variable & $\begin{array}{c}\text { Antilog of } \\
\text { coefficient }\end{array}$ & $\begin{array}{c}\text { Implicit } \\
\text { Price }\end{array}$ & $\mathbf{P}[|\mathbf{Z}| \mathbf{z}]$ \\
\hline Quantity & 1.00 & 0.057 & 0.050 \\
\hline Frequency of supply & 1.75 & 9.02 & 0.078 \\
\hline Quality & - & - & 0.335 \\
\hline Price & 1.06 & 1 & 0.000 \\
\hline Productive uses & - & - & 0.743 \\
\hline
\end{tabular}

McFadden $R^{2}=0.17 ;$ Number of households $=30$

\section{TABLE 5}

Sub-Stratum 2b. Households with private tap and higher water consumption

\begin{tabular}{|l|c|c|c|}
\hline Variable & $\begin{array}{c}\text { Antilog of } \\
\text { coefficient }\end{array}$ & $\begin{array}{c}\text { Implicit } \\
\text { Price }\end{array}$ & $\mathbf{P}[|\mathbf{Z}|>\mathbf{Z}]$ \\
\hline Quantity & 1.01 & 0.071 & 0.027 \\
\hline Frequency of supply & - & - & 0.552 \\
\hline Quality & 4.17 & 17.24 & 0.037 \\
\hline Price & 1.09 & 1 & 0.000 \\
\hline Productive uses & 8.61 & 26.02 & 0.063 \\
\hline
\end{tabular}

McFadden $R^{2}=0.24 ;$ Number of households $=57$

\section{Household's income and preferences for water services}

Another aspect considered worth to be analysed was the household income, as this could explain current access to water services or the capacity to pay water service improvements. Surveyed households were therefore split into two groups on the basis of per capita monthly income. The income variable was then crossed with the 'availability of private tap' to obtain four sub-strata: 'households without private tap and lower income' (sub-stratum 1c); 'household without private tap and higher income' (SubStratum 1d); 'households with private tap and lower income' (Sub-Stratum 2c); and 'households with private tap and higher income' (Sub-Stratum 2d). Median income in the entire sample was calculated at R $8.04 / \mathrm{cap} \cdot \mathrm{d}$. It was therefore decided to consider 'poor households' those earning less than the median income per capita, corresponding, for a family of 6 members, to R1 450/month. Due to the few observations available for poor households having private taps, CLM was applied only to the two sub-strata referring to households without private taps. Tables 6 and 7 show the results of CLM applied to these sub-strata.

\section{TABLE 6}

Sub-Stratum 1c. Households without private tap and lower income

\begin{tabular}{|l|c|c|c|c|}
\hline Variable & $\begin{array}{c}\text { Coeffi- } \\
\text { cient }\end{array}$ & $\begin{array}{c}\text { Antilog } \\
\text { of coef- } \\
\text { ficient }\end{array}$ & $\begin{array}{c}\text { Implicit } \\
\text { price }\end{array}$ & $\mathbf{P}[|\mathbf{Z}|>\mathbf{z}]$ \\
\hline Quantity & $0.003^{*}$ & 1.01 & 0.07 & 0.090 \\
\hline $\begin{array}{l}\text { Frequency of } \\
\text { supply }\end{array}$ & $0.496^{* * *}$ & 3.14 & 11.27 & 0.004 \\
\hline Quality & $0.930^{* *}$ & 8.51 & 21.14 & 0.045 \\
\hline Price & $-0.044^{* * *}$ & 1.11 & 1.00 & 0.000 \\
\hline Productive uses & -0.190 & - & -4.32 & 0.780 \\
\hline Water source & $1.036^{* * *}$ & 10.87 & 23.55 & 0.005 \\
\hline
\end{tabular}

McFadden $R^{2}=0.20 ;$ Households number $=27$

\section{TABLE 7}

Sub-Stratum 1d. Households without private tap and higher income

\begin{tabular}{|l|c|c|c|c|}
\hline Variable & $\begin{array}{c}\text { Coeffi- } \\
\text { cient }\end{array}$ & $\begin{array}{c}\text { Antilog } \\
\text { of coef- } \\
\text { ficient }\end{array}$ & $\begin{array}{c}\text { Implicit } \\
\text { price }\end{array}$ & $\mathbf{P}[|\mathbf{Z}|>\mathbf{z}]$ \\
\hline Quantity & $0.005^{* *}$ & 1.01 & 0.15 & 0.013 \\
\hline $\begin{array}{l}\text { Frequency of } \\
\text { supply }\end{array}$ & $0.682^{* * *}$ & 4.81 & 20.46 & 0.001 \\
\hline Quality & 0.574 & & & 0.246 \\
\hline Price & $-0.033^{* * *}$ & 1.08 & 1.00 & 0.001 \\
\hline Productive uses & 0.235 & 1.72 & & 0.470 \\
\hline Water source & $1.149^{* * *}$ & 14.10 & 34.48 & 0.007 \\
\hline
\end{tabular}

McFadden $R^{2}=0.18 ;$ Households number $=56$ 
It is clear that the higher elasticity to water price for households with a lower income has a negative impact on their WTP for all attributes. Access to a private tap is still the most sensitive attribute for both sub-strata, while frequency of supply seems to be the $2^{\text {nd }}$ priority for relatively wealthier households and water quality is the second highest concern for poorer households.

\section{Conclusions and policy implications}

IWRM in developing countries must take into account the efficient and equitable allocation of water to rural domestic users. The analysis conducted in the Sekororo-Letsoalo area showed that local inhabitants are not happy with the current level of domestic water provision. In many cases, local households do not have access to sufficient water to satisfy their basic needs, and even when the RDP standard is reached, little or no water is available for non-domestic uses. Interestingly, for all groups of households the quality of water services in terms of distance, reliability and water quality seems to be more important than the quantity of water delivered. Getting access to a private tap is the most important improvement in terms of water services desired by households currently supplied from standpipes, rivers, or boreholes.

Productive uses of domestic water are not common in the studied area and this seems to be due to the low availability of water, which forces local households to be concerned first of all about basic domestic uses. A clear interest to engage in multiple uses was observed only in those households that already have enough water to satisfy basic domestic needs. This result would indicate that very poor conditions in terms of water availability not only reduce drastically the current livelihood of rural households, but also affect their ambitions and willingness to improve their status.

Unlike other valuation techniques such as the CVM or the travel-cost method (TCM), CM provides in-depth information about water users' preferences and WTP for different characteristics of water services. This information is crucial for water service authorities and providers in order to tailor the provision of these services and the corresponding price based on the local water demand.

The calculated WTP per household in the study area is very comparable to the one observed in similar rural conditions using different techniques (CVM and TCM) by Banda et al. (2006 and 2007) and demonstrates that, despite the extremely poor economic conditions of local households, there is room for the adoption of cost-recovery mechanisms, provided that the water services proposed respond to users' demand. The study also showed that preferences and WTP of households vary according to their present access to water (type of access and level of consumption) and their level of income. As expected, price elasticity of demand is higher for households with lower income or higher level of consumption. Therefore it might be important to offer rural households several options in terms of quality of services and associated tariffs to better match their requirements and ability to pay. As emphasised in previously published work (Cardone and Fonseca, 2003; Komives et al., 2005), while cost-recovery for water provision is possible in poor rural contexts, the level and structure of tariffs and the technological options chosen to implement these tariffs should be carefully studied case by case to increase the probability of success of the programme. Further analysis is needed to compare household WTP with the cost of various technological options for rural water services to better assess the potential for cost-recovery.

In conclusion, $\mathrm{CM}$ applied to the Sekororo-Letsoalo area showed the utility of stated preferences methods to elicit local residents' demand characteristics and WTP for various aspects of water services and uses. The combined use of other economic methods in addition to the $\mathrm{CM}$ (for instance, revealed preference methods such as the TCM or a dichotomous choice method such as the CVM) would certainly improve the accuracy of the results and increase their soundness.

\section{Acknowledgements}

This study was conducted within the SAFeWater ARISE Water Management and the MUS projects. The latter is a part of the CGIAR Challenge Program on Water and Food. We thank the French Ministry of Foreign Affairs for supporting this research under the FSP Echel-EAU Program. We are also grateful to the people from Sekororo-Letsoalo area for their participation to the survey. Finally we would like to express our gratitude to J Snowball and E Biénabé for their methodological suggestions and to the two anonymous reviewers for their valuable comments.

\section{References}

AQUASTAT (2005) http://www.fao.org/ag/agl/aglw/aquastat/countries/ south_africa/index.stm Accessed in March, 2007.

ADAMOWICZ V (1995) Alternative Valuation Techniques: A Comparison and Movement to a Synthesis. In: KG Willis and JT Corkindale (eds.) Environmental Valuation: New Perspectives. CAB International.

ADAMOWICZ W, LOUVIERE J and SWAIT J (1998) Introduction to Attribute-Based Stated Choice Methods. Final Report. Resource Valuation Branch Damage Assessment Center NOAA - National Oceanic and Atmospheric Administration US Department of Commerce.

ANAND P B (2001) Consumer preferences for water supply? An application of choice models to urban India. Discussion paper No. 2 001/105. United Nations University. WIDER.

BANDA BM, FAROLFI S and HASSAN RM (2006) Determinants of quality and quantity values of water for domestic uses in the Steelpoort sub-basin: a contingent valuation approach. In: Perret, S Farolfi S and Hassan RM (ed.) Water Governance for Sustainable Development. Earthscan, London. 167-188.

BANDA BM, FAROLFI S and HASSAN RM (2007) Estimating water demand for domestic use in rural South Africa in absence of price information. Water Policy 9 (5) 513-528

BEN-AKIVA M and LERMAN SR (1985) Discrete Choice Analysis: Theory and Application to Travel Demand, The MIT Press.

BLAMEYR, GORDON J and CHAPMAN R (1999) Choice modelling: Assessing the environmental values of water supply options. Aust. J. Agric. Resour. Econ. 43 (3) 337-357. DOI:10.1111/14678489.00083.

CARDONE R and FONSECA C (2003) Financing and Cost Recovery. Thematic Overview Papers. International Water and Sanitation Centre (IRC) Delft, theNetherlands.

DWAF (2003) Scheme Summary Report. Various Schemes, Department of Water Affairs and Forestry, Pretoria, South Africa.

DWAF (2004) National Water Resource Strategy. Department of Water Affairs and Forestry, Pretoria, South Africa.

FAROLFI S, MABUGU RE and NTSHINGILA S (2006) Domestic water uses and values in Swaziland: A contingent valuation analysis. Agrecon 46 (1) 157-170.

GREENE WH (2007) NLogit Version 4.0 Reference Guide, Econometric Software Inc.

GREENE WH (2000) Econometric Analysis (4th edn.) Prentice Hall, USA.

GOLDBLATT M (1999) Assessing the effective demand for improved water supplies in informal settlements: a willingness to pay survey in Vlakfontein and Finetown, Johannesburg. Geoforum 30 (1) 27-41.

HANLEY N, MOURATO S and WRIGHT RE (2001) Choice model- 
ling approaches: a superior alternative for environmental valuation? J. Econ. Surv. 15 (3) 435-462.

HOPE RA, DIXON PJ and VON MALTITZ G (2003) The role of improved domestic water supply in livelihoods and poverty reduction in Limpopo Province, South Africa. Proc. Int. Symp. on Water, Poverty and Productive Uses of Water at the Household Level. 21-23 January 2003, Muldersdrift, South Africa.

HOPE RA and GARROD GD (2004) Is Water Policy Responding to Rural Preferences? A Choice Experiment Model Evaluating Household Domestic Water Trade-Offs in Rural South Africa. CAMP-TR 8.

HOPE RA (2006) Evaluating water policy scenarios against the priorities of the rural poor. World Dev. 34 (1) 167-179.

KUHFELD F (2000) Multinomial Logit, Discrete Choice Modelling - An Introduction to Designing Choice Experiments, and Collecting, Processing, and Analysing Choice Data with the SAS System. Technical Support Document, SAS Institute Inc. Available at: http://www.stat.auckland.ac.nz/ balemi/Choice.pdf

KOMIVES K, FOSTERV, HALPERN J and WODON O (2005) Water, Electricity and the Poor. Who benefit from Utility Subsidies? The World Bank, Washington, DC.

KOUTSOYANNIS A (1992) Theory of Econometrics (2 $2^{\text {nd }}$ edn.). Macmillan, New York.

LEFEBVRE M, MORARDET S, MONTGINOUL M and FAROLFI S (2005) How to Finance Multiple Use Water Systems for the Rural Poor? Lessons Learnt from the Domestic Water Sector in the Olifants River Basin, South Africa. Communication to the International Workshop 'Water Poverty and Social Crisis'. 12-15 December, Agadir, Morocco.

LOUVIERE JJ (1996) Relating Stated preferences Measures and Models to Choices in Real Markets: Calibration of CV Responses. In: David J Bjornstad and James R Kahn (eds.) The Contingent Valuation of Environmental Resources: Methodological Issues and Research Needs. Edward Elgar, Cheltenham, UK. 167-188.

McFADDEN D (1973) Conditional Logit Analysis of Qualitative Choice Behaviour. University of California,Berkeley, California, USA.

NAM P and SON T (2005) Households Demand for Improved Water Services in Ho Chi Minh City: A Comparison of Contingent Valuation and Choice Modelling Estimates. Research report \# 2005RR\#, Economy and Environment Program of South East Asia. http://www.eepsea.org .

NICKLITSCHEK M and LEON J (1996) Combining intended demand and yes/no responses in the estimation of contingent valuation models. J. Environ. Econ. Manage. 31 387-402.

NIEUWOUDT WL, BACKEBERG GR and DU PLESSIS HM (2004) The value of water in the South African economy: Some implications. Agrekon. 43 (2) 162-183.

PATTANAYAK SK, VAN DEN BERG C, CHEN YANG J and VAN HOUTVEN G (2006) The use of willingness to pay experiments: Estimating demand for piped water connections in Sri Lanka. World Bank Policy Research Working Paper 3818, January edition.

PANESAR J (2006) The Gendered Nexus between Formal Institutions and Informal Networks for Water Resources Management in South
Africa. M.Sc. Thesis, Faculty of Graduate Studies, University of Guelph, Ontario, Canada.

REPUBLIC OF SOUTH AFRICA (1997a) White paper on a National Water Policy for South Africa.

REPUBLIC OF SOUTH AFRICA (1997b) Water Services Act (108 of 1997).

REPUBLIC OF SOUTH AFRICA (1998) National Water Act (36 of 1998).

SMITS S, COUSINS T, DHLAMINI V, GUZHA E, VAN KOPPEN B, MAKONI F and MALULEKE T (2006) Multiple uses of water to enhance poor people's livelihoods - relevance for the SADC region. Background Paper for the Session on 'Multiple Uses of Water at the Household Level.' Proc. WARFSA Conf. 2 Nov 2006, Lilongwe, Malawi.

SNOWBALL D, WILLIS KG and JEURISSEN C (2007) Willingness to pay for water service Improvements in middle-income urban households in South Africa: A stated choice analysis. Proc. ESSA 2007 Conf., 10-12 January, Johannesburg.

SPEELMAN S, FAROLFI S, PERRET S, D'HAESE L and D'HAESE M (2008) Irrigation water value at small-scale schemes: evidence from the North West Province, South Africa. Int. J. Water Resour. Dev. 24 (4) 621-633.

STATISTICS SOUTH AFRICA (2007) Census 2001. http://www. statssa.gov.za

TUMBER FOURIE CONSULTING ENGINEERS (2003a) Water Services Development Plan for the Bohlabela District Municipality. Final Draft, 30 September 2003. Bohlabela District Municipality, DWAF.

TUMBER FOURIE CONSULTING ENGINEERS (2003b) Water Services Development Plan for the Maruleng Municipality. Final Draft. 29 August 2003. Bohlabela District Municipality, DWAF.

VAN KOPPEN B, MORIARTY P and BOELEE E (2006) Multiple-Use Water Services to Advance the Millennium Development Goals. International Water Management Institute (IWMI) Research Report 98. IWMI South Africa?

WHITTINGTON D, MU X and ROCHE R (1990) Calculating the value of time spent collecting water: Some estimates for Ukunda, Kenya. World Dev. 18 (2) 269-280.

WHITTINGTON D, DAVIS J and McCLELLAND E (1998) Implementing a demand-driven approach to community water supply planning: A case study of Lugazi, Uganda. Water Int. 23 (3) 134-145.

WILLIS KG, SCARPA R and ACUTT M (2005) Assessing water company customer preferences and willingness-to-pay for service improvements: a stated choice analysis. Water Resour. Res. 41 1-11 (February issue).

WORLD VISION (2005a) Enable Area Development Programme, Baseline Survey Report, World Vision, Johannesburg, South Africa.

WORLD VISION (2005b) Kodumela Area Development Programme, Baseline Survey Report, World Vision, Johannesburg, South Africa.

YANG J, PATTANAYAK SK, JONSON FR, MANSFIELD C, VAN DEN BERG C and JONES K (2006) Unpackaging demand for water service quality: Evidence from conjoint surveys in Sri Lanka. World Bank Policy Res. Working Paper 3817 (January issue). 